\title{
The Development of Kayuh Baimbai Cooperative Learning Model for Elementary School Students
}

\author{
Akhmad Humaidi, Yudha Adrian \\ STKIP PGRI Banjarmasin \\ Banjarmasin, Indonesia \\ humaidi.a@stkipbjm.ac.id
}

\begin{abstract}
This research was conducted to develop Kayuh Baimbai cooperative learning model based on local wisdom of Banjarese community. This cooperative learning model was applied on Bahasa Indonesia subject in fourth grade students. Kayuh Baimbai cooperative learning model emphasized on togetherness or collaboration in group. The preliminary philosophy of cooperative learning model is buying and selling activity on floating market in Banjarmasin. This cooperative learning model could enable learners to be active in learning activity. The research used Borg and Gall design that has three main steps, which are collecting research and information, planning product, developing a preliminary and operational product testing. This research was conducted at SDN Pemurus Dalam 1 on fourth grade with 23 students. The results of the validators pointed out that model is valid and can be used for field testing. The instruments used were pretest and posttest by Levene's test for equality of variances. The results showed the value was $P=0.103>0.005$ included into the category of homogeneous. So, the instrument is qualified to be tested. The result calculated $t$-test significance level at $5 \%$, and the t-test on student achievement has showed value less than $0.05(p<0.05)$. Therefore, kayuh baimbai cooperative learning model gives impact on student achievement and is effectively used.
\end{abstract}

Keywords—cooperative learning; kayuh baimbai

\section{INTRODUCTION}

This Floating Market is the hallmark of a tourist destination in South Kalimantan. Banjarese people have been buying and selling products on boat in the river before sunrise. This activity has been going on for hundreds of years and it continues to survive until today. It reflects the deep local culture of Banjarese community. They are very close to the river life and have a high togetherness. Togetherness is very much needed even in the digital era, and therefore, it should be attempted to embed it to the younger generation as early as possible. Formal education is a very appropriate place for instilling values of togetherness to the children in the current global era. Education should not only lead to the development of the individual, but also how to make them work together to build their environment better. The learning objectives in the curriculum should provide the knowledge and skills to solve social problems for improving quality of life [1]. However, instilling value is not necessarily through the learning materials. The learning activities in the form of indirect learning model can also be used as a means of instilling value.
The best appropriate approach to do that is through cooperative learning. This approach is very effective to train students to work in groups. Various studies have proved that this approach is able to provide many positive effects for students. Cooperative Learning enable students to practice learning skills in general. The students believe that the cooperative learning is effective enough to make them master the skills they are learning in general [2]. Students' achievement also increases after the cooperative learning is implemented. Students show satisfaction when working in groups. Cooperative learning is generally proven to help improve student achievement [3].

Students who work in groups will require adjustments and earnest effort to succeed. Cooperative learning does require an adjustment in the beginning, but if it is successful, learning outcomes would likely be better than individual learning system. Ref [4] found out the test results in his research that in the beginning it was more effective individualistic learning because at that time the team development was going on in the learning group. However, in a longer period, cooperative learning becomes more effective than individualistic learning. In addition, the working in group is also more favorable to students. Ref [5] strengthens the excellence of cooperative learning. His research proves that students are much happier to learn and complete the task in groups. They can develop a positive attitude that is unthinkable with a suitable environment so that an increase in the student's skills may occur. Nonetheless in the future, the next generation should be able to interact in a global team to achieve the same goal.

Kayuh Baimbai learning model belongs to the cooperative learning. This learning requires cooperation among students and interdependence in the structure of task achievement, goals, and rewards [6]. Kayuh Baimbai is derived from two words; those are "kayuh" which means paddle and baimbai which means together. Literally, the word means paddling together. This term is taken from cultural philosophy of Banjarese people which means doing various activities together to achieve a goal.

Kayuh Baimbai model was adopted from two cooperative models, the model of Student Team Achievement Division (STAD) and Quiz-Quiz Trade. STAD adopted stage lies in the assessment system in which answers are counted as the value of the group. STAD is proven to improve students' skills. Ref. 
[7] showed that STAD proves to be more effective than traditional methods of activating students. Each member is required to participate in learning activities to answer any questions in turns. The group score is obtained from the total number of answers given by each member. This system would make every group has a responsibility to answer the questions they get. Adopted Quiz-Quiz Trade phase lies in the exchange system of material question. The main principle of this model is student quiz, get the quiz from a partner, and then trade cards to repeat the process with a new partner [8]. This system will encourage interaction between one group and another group so that learning becomes more attractive.

Kayuh Baimbai model is an illustration of Banjarese people activity at floating market that is located in South Kalimantan. Students are directed to play as a trader on a boat in floating market. They trade goods to fulfill their needs. They row together to a market in the river with holding shoulder of each other. In the market, they interact each other to exchange goods. In this model, this exchange was showed in the form of questions or lesson material. A group is one unity; therefore, to get a high score they must work together.

There are seven phases to be conducted by the students when practicing Kayuh Baimbai mode, i.e. groups, asking questions, exchanging, answering alternately, counting scores, and awards. The discussion of each step is as follows.

Phase 1: Grouping. Students form groups of 3-5 students. A group reflects a boat. Each member mutually needs each other to get the best title.

Phase 2: Material Explanation. The teacher gives each group a material that would become their specialty. Each group is asked to present the material and the other group listens. Each group would try to understand the material of each group to determine who they would choose at the later stage.

Phase 3: Receiving questions. Each group receives a question that has been designed by teachers based on the number of group members. Questions refer to the theme and the material they have presented. Each question includes the name of the group. It encourages the participation of each member to complete the tasks assigned by the teacher. The question would be given to another group. Instead, each group receives questions from other groups to be answered.

Phase 4: Exchanging. Each group goes to the middle of the class along with holding their peers' shoulder and meets other groups to exchange questions. Holding the shoulder reflects a boat and every member paddles together to run it.

The exchange should be done equally. Every member must get questions from members of other groups. Questions should not be taken from one group only. The number of questions obtained determines the number of points they can get for the group. At least one question must be possessed by every group. The rest can choose which group they prefer, so the possibility of correct answer is going to be higher. In addition, the exchange must be in continuous motion. Exchange in the floating market occurs in the streams that move so that the exchanging groups are also conditioned that way. This regulation would also provide challenges for students so that activity becomes more interesting.

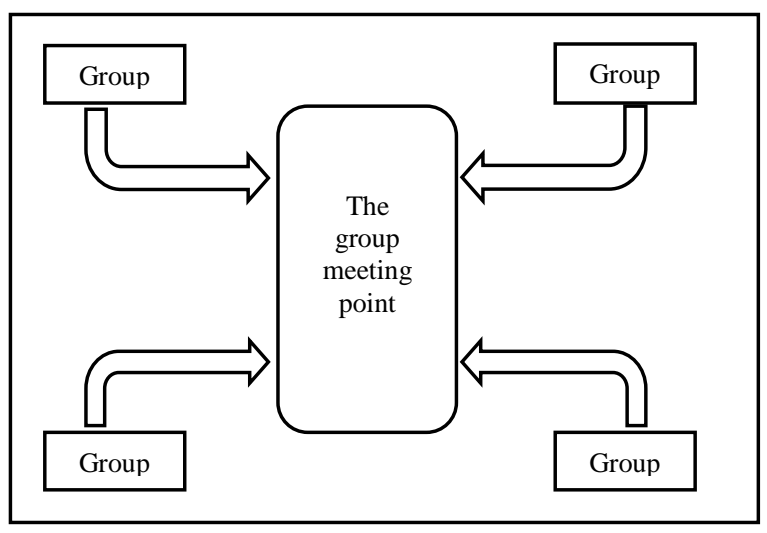

Fig. 1. Exchanging questions of each group

Phase 5: Answering alternately. Each group in turn answers the questions. Questions are answered by the members of each group when the exchange occurs. The questions they get should be answered by himself and cannot be represented. However, the correct answer would benefit the group so that other members also take responsibility to help answer these questions.

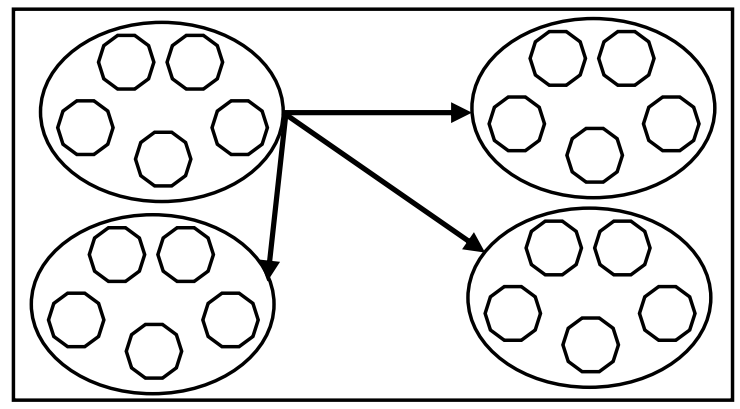

Fig. 2. Every group answers other groups' questions

Fase 6: Accumulating Individual Scores and Group Scores. Scores are divided into two, namely the individual score and the group score. Each member has to get the same initial score, which is 50. Each correct answer gets 10 points for individuals who answer and extra points for the group. If the answer given is wrong, the individual will lose 5 points so that points of the group are also reduced. Each member must ensure that their friends are able to answer the questions. Calculation of individual scores can be observed in Table 1 .

TABLE I. THE CALCULATION OF INDIVIDUAL SCORE

\begin{tabular}{|l|c|}
\hline \multicolumn{1}{|c|}{ Category } & Score \\
\hline 10 points under the initial score & 0 point \\
$1-10$ points under the initial score & 10 point \\
$1-10$ points above the initial score & 20 point \\
10 points above the initial score & 30 point \\
\hline
\end{tabular}

The beginning of each individual score will increase successfuly if they answer questions correctly. The total points 
of the group members will determine the group score. The calculation of the group score can be observed in Table 2.

\begin{tabular}{|c|c|}
\multicolumn{1}{c}{ TABLE II. } & GROUP TITLE \\
\hline Average of individual score & Title \\
\hline $0 \leq \mathrm{x} \leq 5$ & - \\
$5 \leq \mathrm{x} \leq 15$ & Good team \\
$15 \leq \mathrm{x} \leq 25$ & Great team \\
$25 \leq \mathrm{x} \leq 30$ & Super team \\
\hline
\end{tabular}

Score is derived from the number of overall group score of each group member divided by the number of group members. Total scores will determine reward they will earn.

Phase 7: Reward. The group who gets the most points will be awarded. The higher score the group get the higher reward will be given. Rewards are given to groups rather than individuals. It will show how the interest of the group is more valued than the individual.

\section{METHOD}

The method used in this study was research and development ( $\mathrm{R} \& \mathrm{D}$ ). This method is a strategy or research method that is powerful enough to improve practice [9]. Ref. [10] said that R \& D bridges the existing gaps between basic and applied research by bringing the finding of the basic and applying research together to create the conceptualized and tested product ready to be used in classrooms.

This research was classified as development research that adapted Borg \& Gall model, so it is divided into 6 stages of research. The steps are; (1) research and collecting information (research and data collection), (2) planning (planning) (3) developing a preliminary form of the product (the development of the initial draft products) (4) preliminary field testing (early field trials); (5) revising the main product (revie the results of the initial field trials); (6) testing the field (field trials).

However, there were only some steps used in this research, due to the limited time, effort, and research funds. Generally, this research method was divided into three main stages, namely the introduction, design, and development and evaluation. The preliminary stage consisted of literature studies, field surveys, and drafting products. The design stage included the initial design model in the form of lesson plan, lesson material and assessment, which were reflected on Lesson Plan and the atributes. Development and evaluation stages included trials product which consisted of testing experts and field trials. The purpose of testing expert was to get advice and input from initial design product. The field trial was conducted in one class to see the level of practicality. The results of field trials become the basic model repairment before being a final product.

Design validation of learning model was performed by two people, namely 1 lecturer (as expert validator) and 1 teacher (as user validator). The field trial was conducted in SDN Pemurus Dalam 1 in the fourth grade with 22 students in order to determine the effectiveness of the learning model developed.
SDN Pemurus Dalam 1 was chosen as the research site because this school is located in urban areas. This location reflects the nature of the heterogeneity of the students because urban area is engaged by various groups of people from various ethnic groups, the level of social, economic, education, and culture. This condition was very compatible with the goal of cooperative learning that tries to combine the different.

\section{RESULT AND DISCUSSION}

\section{A. Expert Validity}

Model validation process included the initial product assessment carried out by two validators. The result of validation tests showed high levels of validity or accuracy of the phases of learning models. The recapitulation of validation results can be observed in Table 3 .

TABLE III. THE RECAPITULATION OF EXPERT AND USER VALIDATOR

\begin{tabular}{|c|c|c|c|}
\hline No & Validator & Scores & Category \\
\hline 1 & Lecturer & 92 & Highy valid \\
2 & Teacher & 83 & Valid \\
\hline
\end{tabular}

The data in Table 3 showed that Kayuh Baimbai learning model was highly valid. Therefore, it chould be tested on a small scale. In addition, the validation results of teachers/users also indicated that Kayuh Baimbai cooperative learning model was valid (it chould be used with minor revisions before been tested on a small scale).

\section{B. Field Testing}

Kayuh Baimbai learning model was tested on a small scale in SDN Pemurus Dalam 1 Banjarmasin. This trial used experimental design with one group pretest-posttest. The implementation of field-testing could be observed on the following design [11].

\begin{tabular}{|l|l|l|}
\hline $\mathrm{O} 1$ & $\mathrm{x}$ & $\mathrm{O} 2$ \\
\hline
\end{tabular}

Figure 3. One group pretest-posttest design

Where are $\mathrm{O} 1$ : prettest, $\mathrm{O} 2$ : posttest, and $\mathrm{X}$ : Treatment implemented by Kayuh Baimbai Model

The effectiveness testing of the Kayuh Baimbai learning model used test instrument in multiple-choice form. Before the data were analyzed using t-test, the data were analyzed by using normality and homogeneity tests.

The results of the pretest were tested using KolmogorovSmirnov $\mathrm{P}=0.356>0.005$ so that the value was considered normal. The results of posttest were analyzed using the Kolmogorov-Smirnov test with a value of $0.163>0.005$, so the value was categorized normal.

The pretest and posttest results were computed using Levene's test for equality of variances $P=0.103>0.005$. In short, the data were homogeneous. Thus, the data of student 
learning outcomes were qualified and to be tested using a ttest aided SPSS version 20. The effectiveness of the model was determined by using the t-test in SPSS version 20. Based on analysis of t-test on prettest and posttest, the $p$-value was smaller than $0.05(\mathrm{p}<0.05)$. It indicated that Kayuh Baimbai learning model affected students' achievement. In other words, Kayuh Baimbai learning model had effectiveness.

\section{Discussion}

Kayuh Baimbai learning model seems very helpful at field trials to improve motivation and ability of students to learn. The material choosen in this trial was about intensive reading. This material was choosen because reading requires the students' ability to concentrate on finding answers. This material requires the students' ability to find the main idea in each paragraph, answer questions related to the text, and identify the unfamiliar vocabulary. Reading is a receptive language skill that is very basic to be mastered by students before other productive skills.

The initial model design had been through a revision once because of the validator's feedback. Revision lied in the exchange stage. First, the exchange took place as it did without any special requirements and the exchange should be balanced between one group and another group. Users suggested that the exchange take place within a certain time limit so it is not protracted. Method used was by singing together. Many of the positive impacts that arouse when the song was sung together were that the students were more excited, they learned togetherness, and brought out local culture for the selected songs because the songs were Banjarese songs which contain values of togetherness. It also encouraged the students to try to immediately redeem their card with another group because of the limited time available.

Music on a number of studies had indeed shown a positive impact for the listener. Music is proven to build the cognitive process as the segmentation of spoken words into phonemes [12]. Syncronizaion movement with physical movement also proved a positive effect on the ability of the task [13].

The students were very excited when the teacher explained the awards for the best group. Students were not told what gifts they would get, but it did not diminish their enthusiasm to answer questions. The important thing was the appreciation for what they have earned. This attitude seemed much different from the attitude of students taking the pretest. The awards would keep students motivated because their efforts would produce good results.

The third stage of Kayuh Baimbai model, namely receiving questions, also made students interested in taking a series of learning activities. Questions were distributed in the form of cards with four different colors, namely red, green, orange, and blue according to the number of groups. The colors chosen were bright color; therefore, it attracted attention. Most students felt proud and happy to get the color they wanted. On the contrary, others felt sorry for not getting the color they desired. They did not wander for the question they obtained, yet for the color of the card. This had to do with the age of the participants who were still children. Students at this age like the color that attracts attention so much. Color in the research of [14] proved to be a powerful tool to improve the acquisition of textual information.

In the fifth stage, the students took turns to answer questions that they had acquired. They helped each other to answer the questions obtained by each member. The students asked the members of the group when the question was too difficult, so cooperation was completely formed at this stage because when the answer arrived, they were not allowed to ask back to other friends. The assessment process had been done openly on the board, so it was transparent. They could know and control the acquisition of the score they got from the beginning to the end. The teacher straightly wrote down the value they gained or reduction, so all students focused not only when they got a turn, but also when other members answered the questions. Extra score from the start and the reduction when the answer was wrong made students answer the questions very carefully when they took their turn. The success in answering correctly would contribute to the group, while the error would result in a loss not only for the students, but also members of other groups as a whole. The students were very enthusiastic when the question was successfully answered correctly. On the contrary, when their friend made mistake, they look worried because it would drop their positions.

The issue occured when the points collected by the students had been summed. When the trial was going on, there were two groups who received the same score. The solution to resolve this problem was to provide a supplementary question by means of conquest. However, not all students were allowed to answer. The teacher only provided an opportunity for the two groups who received the highest points. In addition, there was only one representative student from each group who was allowed to. Besides, it was easier for the teacher to determine who raised their hands first. This way would also train students to entrust their victory to the group leader or member who was trusted to have the most excellent text mastery. Seizure questions also gives a sense of a fair fight because each group gets an equal chance to succeed.

Kayuh Baimbai model is very useful to train students teamwork in the form of fun cooperative learning. This model would encourage them to learn, but still give pleasure because of the element of the game. They would be encouraged to think creatively so that the group could win the competition. Thus, the students can be trained on the importance of working together to achieve the goal so that the coming generation become a person who is not only concerned with personal interests, but also the interests of the group.

\section{CONCLUSION}

Kayuh Baimbai learning model reflects local wisdom of Banjarese societies that form imitation activities as tradingselling in floating market. Imitation of activities shows 
powerful cooperation on Banjarese societies to achieve their goals. Kayuh Baimbai cooperative learning model is more efficient to practice at schools. Based on expert validation, this model has good validity. At the phase of tested product, this model has normality and homogeneity on pre-test and post-test data in order that the data are able to be analyzed by using t-test. The result of t-test showed that Kayuh Baimbai learning model has significance toward student achievement. Furthermore, this model is effective to implement on the school.

This model was revised by suggestion of expert validator and user validator. This model is able to be developed by other researchers. The suggestions from the researchers are as follows: (1) the next researcher can implement Kayuh Baimbai learning model on different subject matter, (2) implementation of Kayuh Baimbai learning model can be implemented on different grade and level of education, (3) implementation of Kayuh Baimbai learning model can be accompanied by traditional music or tradisional song which is appropriate to school condition.

\section{REFERENCES}

[1] M. Ansyar, Kurikulum: Hakikat, Fondasi, Desain, \& Pengembangan. Jakarta: Kencana, 2015.

[2] J. Ballantine \& M. L. Patricia, "Cooperative learning: A pedagogy to improve students' generic skills?", Education \& Training, 49(2), 126137, 2007. [http://dx.doi.org/10.1108/0040091071 0739487]

[3] R. C. Etchberger, "Assessment of cooperative learning in natural resources education", Journal of Forestry, 109(7), 397-401, 2011. [https://search.proquest.com/docview/900319451? accountid=62696]

[4] C. Hsiung, "The effectiveness of cooperative learning", Journal of Engineering Education, 101(1), 119-137, 2012.

[https://search.proquest.com/docview/1014006079 ?accountid=62696]

[5] A. M. Essien, "Effectiveness of cooperative learning methodology in improving students' learning attitudes towards english language", International Journal of Arts \& Sciences, 8(2), 119-127, 2015. [https://search.proquest.com/docview/1677318451?accountid=62696]

[6] T. I. B. Al Tabany, Mendesain Model Pembelajaran Inovatif, Progresif, dan Kontekstual. Jakarta: Prenadamedia Group, 2015.

[7] F. R. Nikou, A. Bonyadi, K. Ebrahimi, "The effect of student teamachievement division (STAD) on language achievement of iranian EFL students across gender", European Online Journal of Natural and Social Sciences, 3(4), 936-949, 2014.

[8] S. Kagan \& M. Kagan, Kagan Cooperative Learning. San Clemente: Kagan Publishing, 2009.

[https://search.proquest.com/docview/1679263576?accountid=62696]

[9] N. S. Sukmadinata, Metode Penelitian Pendidikan. Bandung: PT Remaja Rosdakarya, 2011.

[10] G. H. Sulistoyo, "Research encompassing feature of 'development' substance associated with teaching and learning in EFL classrooms", in Current Trends on Research Methodology in English Language Teaching, S. Krismanti and T. W. Palupi, Eds. Banjarmasin: STKIP PGRI Banjarmasin, 2016, PP. 1 - 15.
[11] Sugiono, Metode Penelitian Pendidikan: Pendekatan Kuantitatif, Kualitataif, dan R \& D. Bandung: Alfabeta, 2013.

[12] J. E. Gromko, "The effect of music instruction on phonemic awareness in beginning readers", Journal of Research in Music Education, 53(3), 199-209, 2005.

[http://journals.sagepub.com/doi/abs/10.1177/002242940505300302]

[13] M. H. Anshel \& D. Q. Marisi, D. Q, "The effect of music and rhythm on physical performance. Research Quarterly", American Alliance for Health, Physcal Education and Recreation, 49(2) 109-113, 2013.[http://www.tandfonline.com/doi/abs/10.1080/10671315.1978.10 615514]

[14] R. H. Hall \& M. A. Hall, "The effect of color enhancement on knowledge map processing", The Journal of Expremintal Education, 62(3), 209-217, 2010.

[http://www.tandfonline.com/doi/abs/10.1080/00220973.1994.994384 1] 